\title{
ANALISIS FAKTOR - FAKTOR YANG MEMPENGARUHI HARGA SAHAM (STUDI EMPIRIS PADA PERUSAHAAN YANG TERDAFTAR DI LQ 45-BEI TAHUN 2016-2018)
}

\author{
*Fathihani ${ }^{1}$ \\ ${ }^{1}$ Fakultas Bisnis dan Ilmu Sosial, Program Studi Manajemen, Universitas Dian Nusantara, Jakarta, Indonesia
}

*Email Korespondensi:

Fathihani@undira.ac.id

\section{ARTIKEL INFORMASI}

Diterima:

3 March 2021

Direvisi:

15 April 2021

Dipublikasi:

16 Mei 2021

\begin{abstract}
ABSTRAK
Penelitian ini bertujuan untuk menganalisis faktor-faktor yang mempengaruhi harga saham. Populasi dari penelitian ini adalah semua perusahaan yang pernah terdaftar di LQ45 Bursa Efek Indonesia pada periode penelitian tahun 2016-2018. Indeks LQ45 sebagai salah satu indikator indeks saham di BEI dapat dijadikan acuan sebagai bahan untuk menilai kinerja perdagangan saham. Penelitian ini menggunakan data sekunder berupa laporan keuangan tahunan yang diperoleh dari Bursa Efek Indonesia. Teknik pengambilan sampel diambil dengan metode purposive sampling sebanyak 24 perusahaan. Analisis data yang digunakan yaitu regresi linier berganda. Target khusus yang ingin dicapai adalah pembuktian mengenai hipotesis dengan kesesuaian antara teori yang ada dengan fakta yang terjadi sesungguhnya. Menjadikan hasil penelitian sebagai kajian studi kasus perusahaan untuk diimplementasikan dalam mata kuliah dibidang ekonomi khususnya ilmu manajemen.
\end{abstract}

Kata Kunci: Saham, Harga Saham, Net Profit Margin, Earning Per Share, Return on Equity, Price to Book Value

\section{PENDAHULUAN}

Pasar modal sebagai salah satu media investasi keuangan mempunyai berbagai jenis produk yang disebut dengan surat berharga atau sekuritas. Menurut Anorga dan Pakarti (2008:7) pasar modal adalah suatu bidang usaha perdagangan surat-surat berharga seperti saham, sertifikat saham, dan obligasi. Saham adalah tanda penyertaan atau kepemilikan seseorang atau badan usaha dalam suatu perusahaan. Salah satu bentuk investasi yang cukup banyak diminati oleh para investor adalah saham. Mengutip data Bursa Efek Indonesia (BEI), jumlah investor saham per bulan Oktober 2018 mencapai 820.000 investor berdasarkan Single Investor Identification (SID). Pencapaian ini naik signifikan jika dibandingkan dengan jumlah investor saham pada periode tahun 2017 sebesar 628.000 investor saham. Kenaikan sekitar 24\% jumlah investor dalam kurun waktu satu tahun menunjukan bahwa saham merupakan surat berharga yang memiliki daya tarik bagi investor karena dapat memberikan keuntungan yang cukup besar bagi investor walaupun resiko investasi ini juga cukup tinggi.

Pertumbuhan sektor keuangan yang semakin meningkat membuat para investor memburu saham perusahaan pada sektor keuangan. Investor akan melihat laporan kinerja keuangan perusahaan sebelum 
melakukan keputusan untuk menanamkan modalnya atau tidak. Angka dalam laporan keuangan dapat mempengaruhi kepercayaan investor di pasar keuangan. Investor mencari peluang untuk berinvestasi dengan memberikan perhatian khusus pada "harga saham". Harga saham merupakan salah satu alat ukur yang digunakan untuk memberikan informasi tentang keberhasilan pengelolaan suatu perusahaan. Namun, yang menjadi permasalahannya adalah ketidakpastian harga saham. Analisis terhadap harga saham merupakan langkah mendasar yang harus dilakukan oleh investor sebelum melakukan keputusan untuk berinvestasi. Beberapa informasi keuangan yang akan digunakan dalam penelitian ini adalah Net Profit Margin (NPM), Earning Per Share (EPS), Return on Equity (ROE) dan Price to Book Value (PBV).

Sepanjang tahun ini, mayoritas anggota indeks LQ45 menunjukkan penurunan harga saham. Indeks likuid ini pun turun $4,55 \%$ secara year to date (ytd). Akan tetapi, di tengah tren penurunan ini, ada 18 saham yang menunjukkan kenaikan harga. Bahkan, sebanyak enam saham naik lebih dari 30\% per perdagangan. Sahamsaham ini adalah saham PT Bank Tabungan Pensiunan Nasional Syariah Tbk (BTPS) yang naik 117,27\% menjadi Rp 3.900, PT Barito Pacific Tbk (BRPT) 95,61\% menjadi Rp 935, PT Media Nusantara Citra Tbk (MNCN) 79,71\% menjadi Rp 1.249, PT XL Axiata Tbk (EXCL) 74,24\% menjadi Rp 3.450, PT Chandra Asri Petrochemical Tbk (TPIA) 37,55\% menjadi Rp 8.150, dan PT Jasa Marga Tbk (JSMR) 31,43\% menjadi Rp 5.625. Berdasarkan data tersebut investor akan melihat laporan keuangan perusahaan sebelum mereka melakukan investasi. Peranan laporan keuangan menjadi sangat penting dalam proses pengambilan keputusan yang akan diambil oleh para investor. Indikator yang digunakan pada penelitian ini menggunakan rasio dalam laporan keuangan yaitu Net Profit Margin, Earning Per Share, Return on Equity dan Price to Book value.

Net Profit Margin merupakan ukuran untuk mengetahui keuntungan perusahaan karena menunjukan laba bersih yang bisa dihasilkan perusahaan dari kegiatan penjualan atau jasa. Emiten akan dikatakan baik apabila Net Profit Margin tinggi atau hampir mendekati nilai penjualannya. Dampak yang dapat dihasilkan apabila laba bersih meningkat maka dividen yang akan diterima para pemegang saham juga tinggi sehingga saham perusahaan tersebut lebih menarik bagi investor yang ingin mendapatkan keuntungan yang lebih tinggi akan berinvestasi di saham tersebut dan menyebabkan peningkatan harga saham. Earning per Share merupakan rasio yang digunakan untuk menunjukkan jumlah uang yang dihasilkan dari setiap lembar saham biasa. Jika jumlah uang yang dihasilkan meningkat maka nilai perusahaan akan meningkat pula. Earning per share memberikan informasi seberapa besar laba per lembar saham yang menunjukan kemampuan kinerja manajemen dalam mengelola perusahaan. Investor akan tertarik pada nilai Earning Per Share karena hal ini akan memberikan gambaran jumlah dana yang dapat diperoleh mereka untuk setiap lembar saham dan memunculkan harapan mereka yang lebih besar kepada perusahaan dengan kata lain Earning Per Share merupakan sebuah indikator keberhasilan perusahaan di masa lalu dan harapan di masa mendatang.

Return on Equity adalah rasio profitabilitas yang digunakan untuk mengukur tingkat kembali perusahaan atau efektivitas perusahaan dalam menghasilkan laba. Bagi calon investor Return on Equity merupakan aspek pengukuran yang penting untuk mengetahui seberapa efisien perusahaan menggunakan dana yang mereka investasikan untuk menghasilkan laba bersih. Price to Book Value merupakan sebuah rasio yang digunakan untuk membandingkan harga saham dengan nilai bukunya dan memperkirakan harga wajar suatu saham. Bagi investor, Price to Book Value akan berguna untuk membandingkan harga saham yang mereka bayar dengan nilai saham tersebut dan menilai apakah suatu saham tersebut mahal atau murah (valuasi saham).

"Bolten dan Weigand (1998: 77-84, dalam Mulyono 2000: 100) mengatakan bahwa ekspektasi untuk memperoleh pendapatan yang lebih besar di masa mendatang berpengaruh positif terhadap harga saham. Variasi harga saham ditentukan oleh banyak faktor, baik yang berasal dari lingkungan eksternal maupun internal perusahaan. "Rescyana Putri Utami 2017 mengatakan terdapat pengaruh positif terhadap Earning Per Share dan Return on equity Terhadap Harga Saham pada perusahaan industri manufaktur". Indeks LQ45 sebagai salah satu indikator indeks saham di BEI dapat dijadikan acuan sebagai bahan untuk menilai kinerja perdagangan saham. Indeks ini terdiri dari 45 saham yang telah terpilih setelah melalui beberapa kriteria pemilihan sehingga akan terdiri dari saham-saham dengan likuiditas tinggi. Obyek penelitian ini adalah perusahaan yang terdaftar di LQ-45 di Indonesia pada periode 2016-2018 didasarkan pada penelitianpenelitian sebelumnya yang menghasilkan pengaruh yang signifikan terhadap kondisi perusahaan yang terdaftar di LQ-45 yang tercatat di Bursa Efek Indonesia. Berdasarkan penelitian terdahulu, peneliti ingin menguji “ Analisis Faktor-Faktor Yang Mempengaruhi Harga Saham” Studi Empiris Pada Perusahaan yang terdaftar di LQ-45 Bursa Efek Indonesia pada periode penelitian tahun 2016-2018. 


\section{KAJIAN PUSTAKA}

\section{Teori Pensinyalan ( Signaling Theory)}

Siganalling theory menyatakan pengeluaran investasi memberi sinyal positif tentang pertumbuhan perusahaan dimasa yang akan datang, sehingga meningkatkan harga saham sebagai indikator nilai perusahaan (Hasnawati, 2005). Peningkatan hutang juga dapat diartikan pihak luar tentang kemampuan perusahaan untuk membayar kewajibannya dimasa yang akan datang atau resiko bisnis yang rendah, sehingga penambahan hutang akan memberikan sinyal positif. Hal ini dikarenakan perusahaan yang meningkatkan hutang dapat dipandang sebagai perusahaan yang yakin dengan prospek perusahaan dimasa yang akan datang (Brigham dan Houston, 2011). Asumsi utama dari teori sinyal ini memberikan ruang bagi investor untuk mengetahui bagaimana keputusan yang akan diambilnya berkaitan dengan nilai perusahaan tersebut. Akibatnya, ketika financial distress, profitabilitas dan ukuran perusahaan, menunjukan nilai yang berubah, hal ini otomatis memberikan informasi pada investor dalam memberikan penilaian terhadap nilai perusahaan.

\section{Harga Saham}

Harga saham merupakan salah satu faktor yang menyebabkan investor melakukan investasi atas dana yang dimilikinya pada suatu perusahaan dikarenakan melalui harga saham akan tercermin tingkat kinerja perusahaan dan pengembalian modal bagi para investor. Para ahli mengungkapkan pendapat mengenai harga saham, diantaranya: "Harga saham merupakan harga yang terbentuk di bursa saham dan umumnya harga saham itu diperoleh untuk menghitung nilai saham" (Med Press Team Work, 1998) harga saham sangat peka terhadap keadaan. Harga saham akan terus berubah sehingga tidak dapat menjamin ketetapan suatu harga. Sama seperti yang terjadi di pasar pada umumnya, harga saham di pasar modal juga akan bergerak mengikuti hukum permintaan dan penawaran. Dengan pergerakan harga saham inilah yang dapat membawa keuntungan atau risiko bagi para investor. Oleh karena itu investor harus teliti dan berhati-hati sebelum mengambil keputusan investasi agar dapat meraih keuntungan dan bukan kerugian.

\section{Jenis Harga Saham}

Jenis harga saham menurut Sawidji Widiatmojo adalah :

a) Harga Nominal

Harga yang tercantum dalam sertifikat saham yang ditetapkan oleh emiten untuk menilai setiap lembar saham yang dikeluarkan.

b) Harga Perdana

Harga ini merupakan pada waktu harga saham tersebut dicatat di bursa efek.

c) Harga Pasar

Harga pasar adalah harga jual dari investor yang satu dengan investor yang lain.

d) Harga Pembukaan

Harga pembukaan adalah harga yang diminta oleh penjual atau pembeli pada saat jam bursa dibuka.

e) Harga Penutupan

Harga penutupan adalah harga yang diminta oleh penjual atau pembeli pada saat akhir hari bursa.

f) Harga Tertinggi

Harga tertinggi suatu saham adalah harga yang paling tinggi terjadi pada hari bursa.

g) Harga Terendah

Harga terendah suatu saham adalah harga yang paling rendah yang terjadi pada hari bursa.

h) Harga Rata-Rata

Harga rata-rata merupakan perataan dari harga tertinggi dan terendah.

\section{Faktor Yang Menyebabkan Fluktuasi Harga Saham}

Menurut Weston dan Birgham yang dapat mempengaruhi harga saham yaitu:

1) Faktor Internal

Faktor internal yang mempengaruhi harga saham adalah keputusan dividen, struktur permodalan, risiko dan pertumbuhan laba.

2) Faktor Eksternal

Sedangkan faktor eksternal yang mempengaruhi harga saham adalah peraturan yang ada, resesi ekonomi, sentimen pasar, dan lainnya. 


\section{Kerangka Pemikiran}

Berdasarkan kajian pustaka dan penelitian terdahulu maka peneliti merumuskan kerangka penelitian sebagai berikut:

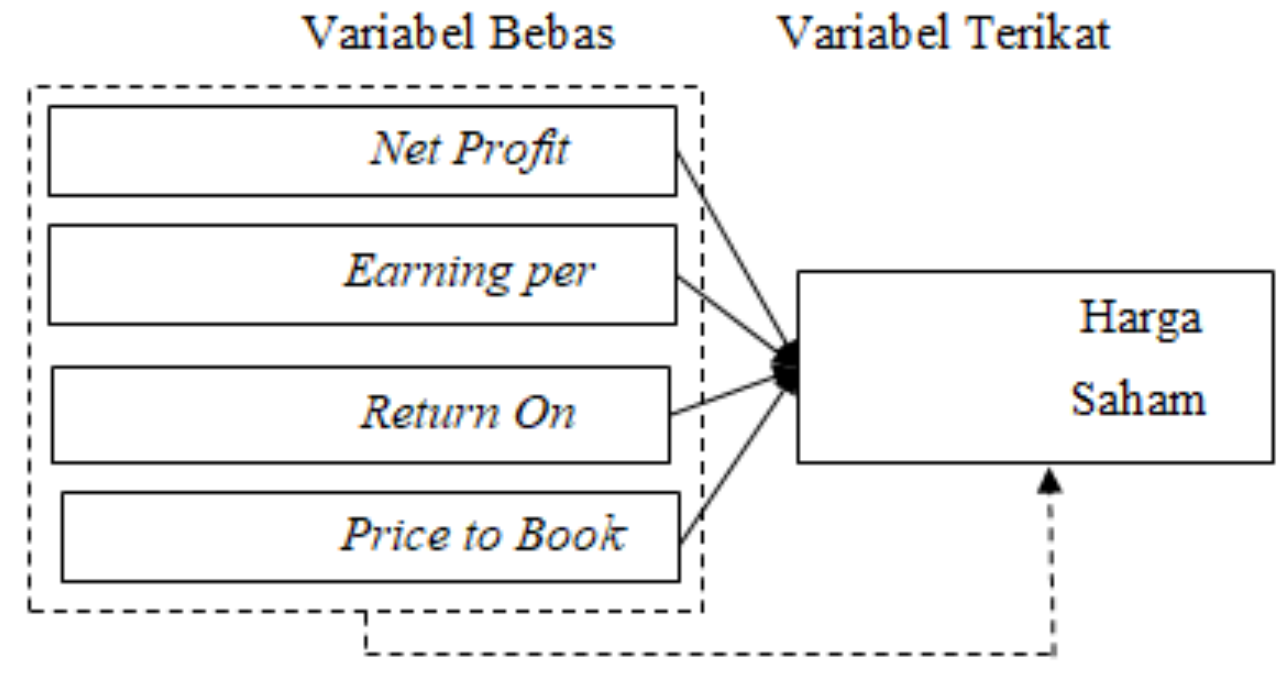

Gambar 1. Kerangka Pemikiran

\section{Hipotesis}

Hipotesa dalam penelitian ini dengan tema pengaruh disiplin dan motivasi kerja terhadap kinerja karyawan ditetapkan sebagai berikut :

H1 : Net Profit Margin berpengaruh positif terhadap Harga Saham

H2 : Earning Per Share berpengaruh positif terhadap Harga Saham

H3: Return on Equity berpengaruh Positif terhadap Harga Saham

H4 : Price to Book Value berpengaruh positif terhadap Harga Saham

\section{METODE}

Pendekatan dalam penelitian ini adalah mengguanakan pendekatan secara kuantitatif, dan berdasarkan tujuannya, jenis penelitian ini adalah kausal yaitu penelitian yang menjelaskan pengaruh suatu variabel bebas (independent variable) terhadap variabel terikat (dependent variable). Variabel independen dalam penelitian ini meliputi Net Profit Margin, Earnings per Share, Return on Equity, Price to Book Value serta untuk variabel dependen dalam penelitian ini adalah Harga Saham. Penelitian dilakukan dengan tujuan menganalisis Net Profit Margin, Earningsper Share, Return on Equity, Price to Book Value terhadap harga saham. Untuk mencapai tujuan penelitian ini, tahapan penelitian dapat digambarkan dalam bagan alir penelitian. 


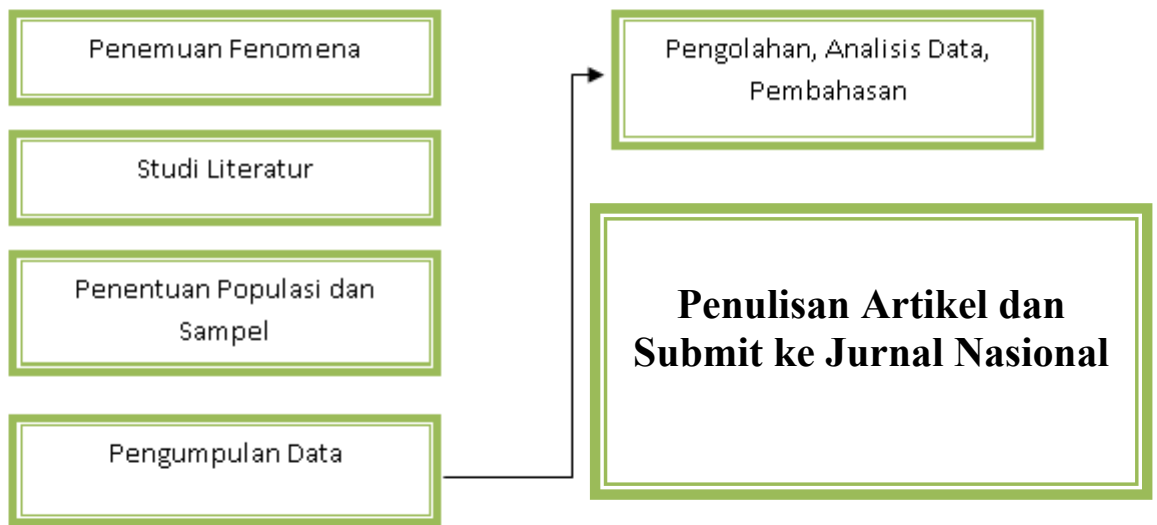

Gambar 2. Tahapan Penelitian

\section{HASIL DAN PEMBAHASAN}

\section{Hasil Pengujian Hipotesis \\ Koefisien Determinasi}

Koefisien determinasi (R2) pada dasarnya mengukur seberapa jauh kemampuan model dalam menerangkan variasi variabel dependen. Nilai koefisien determinasi adalah di antara nol dan satu. Nilai R2 yang kecil memperlihatkan kemampuan variabel independen dalam menjelaskan variabel-variabel sangat terbatas. Nilai yang mendekati satu berarti variabel-variabel independen memberikan hampir semua informasi yang diperlukan untuk memprediksikan variabel-variabel dependen.

Tabel 1. Koefisien Determinasi

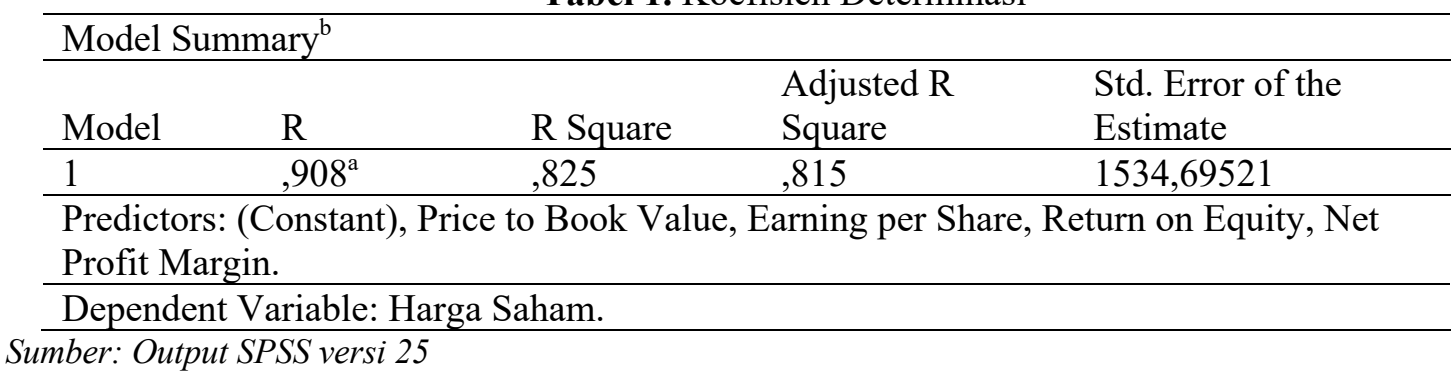

Tabel 5.5 yang tersaji diatas merupakan hasil pengujian koefisien determinasi. Dari hasil pengujian yang telah tersaji diatas, dapat dilihat bahwa nilai r-squared berada diangka 0.815 yang artinya $81.5 \%$ variabel harga saham dijelaskan atau diterangkan oleh keempat faktor yang diujikan yaitu net profit margin, earning per share, return on equity, dan price to book value.

\section{Hasil Pengujian Regresi}

Analisis regresi berganda adalah alat analisis data yang digunakan dalam penelitian ini. Analisis regresi berganda ini dipakai karena untuk menguji pengaruh beberapa variabel bebas (metrik) terhadap satu variabel terikat (metrik) dengan software SPSS. Berikut ini merupakan hasil pengujian regresi:

Tabel 2. Hasil Pengujian Regresi Linear Berganda

\begin{tabular}{clll}
\hline & \multicolumn{2}{c}{$\begin{array}{l}\text { Unstandardized } \\
\text { Coefficients }\end{array}$} & \multicolumn{1}{c}{$\begin{array}{l}\text { Standardized } \\
\text { Coefficients }\end{array}$} \\
\cline { 2 - 4 } & \multicolumn{4}{c}{$\begin{array}{l}\text { Std. } \\
\text { Model }\end{array}$} & $\mathrm{B}$ & Error & Beta \\
\hline (Constant) & 894,532 & 409,172 \\
\hline Net Profit Margin & $-108,410$ & 20,713 &,- 286 \\
\hline Earning per Share & 16,354 &, 962 &, 880 \\
\hline Return on Equity & $-10,870$ & 5,441 &,- 103 \\
\hline
\end{tabular}




\begin{tabular}{ccc}
\hline Price to Book Value $\quad 670,482$ & 105,307 &, 346 \\
\hline Sumber: Output SPSS versi 25 &
\end{tabular}

Berdasarkan dari data tabel 5.6, nilai konstanta regresi linear berganda sebesar 894,532 dengan nilai koefisien regresi variable bebas sebagai berikut :

1) Net Profit Margin sebesar -108,410, yang artinya apabila net profit margin meningkat 1 satuan dan variable lainnya dianggap konstan maka akan meningkatkan harga saham sebesar -108,410.

2) Earning per Share 16,354, yang artinya apabila earning per share meningkat 1 satuan dan variable lain di anggap konstan maka akan meningkatkan harga saham sebesar 16,354 satuan.

3) Return on Equity -10,870, yang artinya apabila nilai return on equity meningkat sebesar 1 satuan dan variabel lain dianggap konstan maka akan menurunkan nilai harga saham sebesar-10,870 satuan.

4) Price to Book Value 670,482, yang artinya apabila nilai price to book value meningkat sebesar 1 satuan dan variabel lain dianggap konstan maka akan meningkatkan harga saham sebesar 670,482 satuan.

$$
\mathbf{Y}=894,532-108,410\left(\mathbf{X}_{1}\right)+16.354\left(\mathbf{X}_{2}\right)-10.870\left(\mathbf{X}_{3}\right)+670.482\left(\mathbf{X}_{4}\right)
$$

Keterangan

$\mathrm{X}_{1}=$ Laba Bersih Setelah Pajak / Penjualan Bersih ( dalam \% )

$\mathrm{X}_{2}=$ Laba Bersih Setelah Pajak / Jumlah Saham Beredar

$\mathrm{X}_{3}=$ Laba Bersih Setelah Pajak / Total Ekuitas ( dalam \% )

$\mathrm{X}_{4}=$ Harga Per Lembar Saham / Nilai buku Per Lembar Saham

\section{Hasil Pengujian Hipotesis Parsial}

Uji statistik t pada dasarnya menunjukkan seberapa jauh pengaruh satu variabel independen secara individual dalam menerangkan variabel dependen. Uji t dapat dilakukan dengan melihat nilai probabilitas signifikansi t masing-masing variabel yang terdapat pada output hasil regresi menggunakan SPSS. Berikut ini merupakan hasil pengujian $\mathrm{t}$ (pengujian secara parsial):

Tabel 3. Hasil Pengujian Secara Parsial

\begin{tabular}{|c|c|c|c|c|c|}
\hline \multicolumn{6}{|l|}{ Coefficients $^{\mathrm{a}}$} \\
\hline \multirow[b]{2}{*}{ Model } & \multicolumn{2}{|c|}{$\begin{array}{l}\text { Unstandardized } \\
\text { Coefficients }\end{array}$} & \multirow{2}{*}{$\begin{array}{l}\text { Standardized } \\
\text { Coefficients } \\
\text { Beta }\end{array}$} & \multirow[b]{2}{*}{$\mathrm{t}$} & \multirow[b]{2}{*}{ Sig. } \\
\hline & $\mathrm{B}$ & Std. Error & & & \\
\hline (Constant) & 894,532 & 409,172 & & 2,186 &, 032 \\
\hline $\begin{array}{l}\text { Net Profit } \\
\text { Margin }\end{array}$ & $-108,410$ & 20,713 &,- 286 & $-5,234$ & ,000 \\
\hline $\begin{array}{l}\text { Earning per } \\
\text { Share }\end{array}$ & 16,354 & ,962 - r - &, 880 & 16,992 & ,000 \\
\hline $\begin{array}{l}\text { Return on } \\
\text { Equity }\end{array}$ & $-10,870$ & 5,441 &,- 103 & $-1,998$ &, 050 \\
\hline $\begin{array}{l}\text { Price to Book } \\
\text { Value }\end{array}$ & 670,482 & 105,307 & ,346 & 6,367 &, 000 \\
\hline pendent Variab & $\operatorname{arga} \mathrm{Sah}$ & & & & \\
\hline
\end{tabular}

Dari hasil penelitian pada tabel 5.7 diatas dapat dilihat bahwa semua variabel memilki tingkat signifikansi dibawah 0.05. Dengan demikian dapat disimpulkan bahwa semua variable bebas berpengaruh terhadap harga saham.

\section{Hasil Pengujian Hipotesis Simultan}


Uji F dilakukan untuk menunjukkan apakah semua variable independen yang dimasukkan dalam model mempunyai pengaruh secara bersama-sama terhadap variabel dependen. Berikut ini merupakan hasil pengujian secara simultan:

Tabel 4. Hasil Pengujian Secara Simultan

\begin{tabular}{llllll}
\hline \multicolumn{7}{c}{ ANOVA $^{\text {a }}$} \\
\hline Model & Sum of Squares & Df & Mean Square & F & Sig. \\
\hline Regression & 744954573,979 & 4 & 186238643,495 & 79,073 &, $000^{\mathrm{b}}$ \\
\hline Residual & 157804389,299 & 67 & 2355289,393 & & \\
\hline Total & 902758963,278 & 71 & & & \\
\hline Dependent Variable: Harga Saham. \\
\hline $\begin{array}{l}\text { Predictors: (Constant), Price to Book Value, Earning per Share, Return on Equity, Net } \\
\text { Profit Margin. }\end{array}$ \\
Sumber: Output SPSS versi 25
\end{tabular}

Tabel 5.8 yang tersaji diatas merupakan hasil pengujian hipotesis secara simultan. Dari hasil pengujian secara simultan yang tersaji pada tabel 5.8 diatas, dapat dilihat bahwa nilai Probabilitas sebesar 0.000 berada dibawah dari taraf signifikansi yaitu 0.05. Dari hal tersebut maka dapat disimpulkan bahwa terdapat pengaruh signifikan secara simultan antara variabel net profit margin, earning per share, return on equity, dan price to book value terhadap harga saham.

\section{Pembahasan}

\section{Pengaruh antara Net Profit Margin terhadap Harga Saham}

Net Profit Margin merupakan salah satu parameter untuk mengukur kinerja keuangan perusahaan. Semakin tinggi rasio Net Profit Margin artinya kinerja perusahaan juga semakin baik, hal ini menunjukan kemampuan perusahaan dalam menghasilkan laba didasarkan dari hasil penjualan yang berdampak pada meningkatnya dividen dan minat para investor sehingga diharapkan dapat berpengaruh terhadap harga saham. Dalam penelitian ini, hasil pengolahan data dan analisis yang telah dilakukan menunjukkan bahwa Net Profit Margin secara parsial berpengaruh signifikan secara negatif terhadap harga saham pada perusahaan LQ-45 yang terdaftar di Bursa Efek Indonesia tahun 2016-2018.Koefisien yang negatif menunjukkan investor cenderung kurang memperhatikan Net Profit Margin dalam pengambilan keputusan pada saat berinvestasi, hal ini dapat disebabkan oleh investor yang lebih memperhatikan faktor lain dalam berinvestasi disebuah perusahaan. Hasil penelitian ini mendukung penelitian yang telah dilakukan oleh Manurung dan Haryanto (2015) dan Egam, et al. (2017), yang memberikan hasil bahwa Net Profit Margin secara parsial berpengaruh signifikan secara negatif terhadap harga saham.

\section{Pengaruh antara Earning Per Share terhadap Harga Saham}

Rasio ini menunjukkan keuntungan yang dihasilkan dari setiap lembar saham. Semakin besar EPS dapat disimpulkan bahwa kinerja perusahaan semakin efektif/baik. Earnings Per Share diperoleh dengan membagi antara Laba bersih setelah pajak dengan jumlah saham yang beredar. Rasio Earning Per Share dapat dijadikan salah satu parameter untuk mengukur kinerja keuangan perusahaan. Semakin.tinggi EPS menunjukan bahwa kinerja perusahaan baik dikarenakan perusahaan bisa menghasilkan pendapatan penjualan yang tinggi dan dapat memberikan laba yang besar untuk investor. Hal ini akan berdampak pada minat investor dalam berinvestasi di perusahaan. Namun sebaliknya jika Earning per Share rendah menunjukkan perusahaan tidak memberikan kinerja yang baik yang tercermin dari pendapatan penjualan yang rendah. Dari hasil penelitian yang dilakukan diketahui bahwa nilai probabilitas dari earning per share adalah sebesar 0.000 dimana nilai tersebut berada dibawah taraf signifikansi yaitu sebesar 0.05 .

Dari hasil tersebut maka dapat disimpulkan bahwa terdapat pengaruh signifikan antara earning per share terhadap harga saham perusahaan atau dengan kata lain besar kecilnya harga saham dipengaruhi oleh earning per share. Tingginya nilai Earning per Share dapat meningkatkan minat investor untuk berinvestasi pada suatu saham, karena jumlah laba yang dibagikan kepada investor akan semakin besar. Begitu juga keadaan sebaliknya, jika nilai Earning per Share kecil akan membuat investor tidak tertarik berinvestasi pada saham tersebut dan mengakibatkan harga saham pada perusahaan akan menurun. Berdasarkan pembahasan tersebut, maka Earning per Share dapat dijadikan pertimbangan oleh investor dalam membuat keputusan untuk 
berinvestasi pada perusahaan LQ-45. Hasil penelitian ini mendukung penelitian yang telah dilakukan, oleh Manurung dan Haryanto (2015), Ujiandari (2015), Wicaksono (2015), Rimbani (2016), Subhan dan Pardiman (2016), Egam, et al. (2017), Sari dan Santoso (2017), Gustmainar dan Mariani (2018), yang memberikan hasil bahwa Earning per Share secara parsial berpengaruh signifikan terhadap harga saham

\section{Pengaruh antara Return On Equity terhadap Harga Saham}

Rasio ini merupakan rasio yang memberikan informasi mengenai kemampuan perusahaan dalam menghasilkan laba dari modal yang dimilikinya. Return on Equity merupakan salah satu rasio yang dapat dijadikan parameter untuk menunjukan kinerja manajemen yang ditunjukan dengan menghasilkan tingkat pengembalian kepada pemegang saham dari pengelolaan modal perusahaan. Jika perusahaan mendapatkan keuntungan dari penggunaan efektifitas modal maka nilai perusahaan yang ditunjukan melalui harga saham akan naik. Para investor tentu akan memperhatikan Return on Equity sebelum mereka mengambil keputusan investasi hal ini dikarenakan Return on Equity yang tinggi dapat menumbuhkan kepercayaan investor kepada perusahaan. Keadaan akan berbalik apabila Return on Equity kecil dapat menandakan pihak perusahaan tidak mampu mengelola modal sehingga investor ragu memberikan kepercayaan pada perusahaan. Hasil pengolahan data dan analisis yang telah dilakukan menunjukkan bahwa Return on Equity secara parsial tidak berpengaruh signifikan terhadap harga saham pada perusahaan LQ-45 yang terdaftar di Bursa Efek Indonesia tahun 20162018. Hubungan negatif antara Return on Equity dengan harga saham menunjukkan bahwa pada saat perusahaan berhasil meningkatkan laba dari penggunaan modalnya, harga saham belum tentu mengalami kenaikan. Hal tersebut menunjukkan kinerja manajemen perusahaan dalam mengelola sumber dana pembiayaan operasional tidak maksimal, sehingga dapat mempengaruhi minat investor dalam berinvestasi karena tingkat pengembalian yang rendah. Hasil penelitian ini mendukung penelitian yang telah dilakukan oleh Wicaksono (2015), Hikmah, et al. (2016), Tyas dan Saputra (2016), Egam, et al. (2017), yang memberikan hasil bahwa Return on Equity secara parsial tidak berpengaruh signifikan terhadap harga saham.

\section{Pengaruh antara Price to Book Value terhadap Harga Saham}

Rasio ini merupakan rasio yang dapat digunakan oleh investor untuk melakukan perbandingan dari sebuah saham dengan saham lain. Suatu saham dapat dikatakan mahal atau murah dapat tercermin dari rasio ini. Price to Book Value adalah salah satu parameter untuk mengukur kinerja perusahaan sehingga mendapatkan pengakuan pasar yang baik sehingga mendapat kepercayaan investor untuk berinvestasi pada perusahaan. Perusahaan dengan kinerja yang baik tentu akan mendapatkan pengakuan pasar yang lebih dari pada perusahaan dengan kinerja kurang baik. Suatu saham dapat disimpulkan mahal apabila nilai Price to Book Value berada di atas angka satu atau saham tersebut overvalue, sedangkan saham yang dikatakan murah adalah saham yang nilai Price to Book Value berada di bawah angka satu atau undervalue. Dari hasil penelitian yang dilakukan, diketahui bahwa nilai probabilitas dari variabel price to book value adalah sebesar 0.0000 dimana nilai tersebut berada dibawah dari taraf signifikansi yaitu 0.05. Dari hasil tersebut dapat disimpulkan bahwa terdapat pengaruh signifikan secara simultan antara price to book value terhadap harga saham dengan kata lain price to book value mempengaruhi harga saham. Berdasarkan pembahasan tersebut, maka Price to Book Value dapat dijadikan pertimbangan oleh investor dalam membuat keputusan untuk berinvestasi pada perusahaan LQ-45. Hasil penelitian ini mendukung penelitian yang telah dilakukan oleh Arviana dan Lapoliwa (2013), Ujiandari (2015), dan Rimbani (2016), yang memberikan hasil bahwa Price to Book Value secara parsial berpengaruh signifikan terhadap harga saham.

\section{Pengaruh Net Profit Margin, Earning per Share, Return on Equity, dan Price to Book Value Terhadap Harga Saham}

Berdasarkan hasil pengolahan data dan analisis yang telah dilakukan hasil pengujian hipotesis menunjukkan nilai $F_{\text {hitung }}>F_{\text {tabel }}$ dan nilai Sig. lebih kecil dari 0,05 artinya secara simultan variabel bebas yaitu Net Profit Margin, Earning per Share, Return on Equity, dan Price to Book Value berpengaruh signifikan terhadap variabel terikat yaitu harga saham pada perusahaan LQ-45 yang terdaftar di Bursa Efek Indonesia tahun 2016-2018. Sehingga dapat disimpulkan secara bersama-sama variabel bebas pada penelitian ini dapat memberikan pengaruh yang besar terhadap harga saham atau nilai yang ada pada variabel Net Profit Margin, Earning per Share, Return on Equity, dan Price to Book Value akan berpengaruh terhadap harga saham perusahaan. Hasil penelitian ini mendukung penelitian yang telah dilakukan oleh Rimbani (2016), yang memberikan hasil bahwa Net Profit Margin, Earning per Share, Return on Equity, dan Price to Book Value secara simultan berpengaruh signifikan terhadap harga saham. 


\section{KESIMPLAN DAN SARAN}

\section{Kesimpulan}

Dari hasil penelitian, maka dapat disimpulkan

1) Net Profit Margin secara parsial berpengaruh signifikan secara negatif terhadap harga saham pada perusahaan LQ-45 yang terdaftar di Bursa Efek Indonesia tahun 2016-2018

2) Earning pershare berpengaruh positif signifikan terhadap harga saham pada perusahaan yang terdaftar pada index LQ45 tahun 2016-2018.

3) Return on equity tidak berpengaruh signifikan terhadap harga saham pada perusahaan yang terdaftar pada index LQ45 tahun 2016-2018.

4) Price to book value berpengaruh positif signifikan terhadap harga saham pada perusahaan yang terdaftar pada index LQ45 tahun 2016-2018.

5) Net profit margin, earning pershare, return on equity dan price to book value berpengaruh signifikan secara simultan terhadap harga saham pada perusahaan yang terdaftar pada index LQ45 tahun 2016-2018.

\section{Saran}

Dari kesimpulan diatas maka peneliti memberikan saran sebagai berikut:

1) Bagi peneliti selanjutnya agar dapat melakukan penelitian pada sektor lain guna memperoleh informasi lebih baik mengenai harga saham.

2) Memperbaharui periode penelitian untuk periode yang akan datang.

3) Menambahkan variabel variabel lain yang berkaitan dengan harga saham.

\section{REFERENCES}

Agnes Sawir, (2009). Financial Performance Analysis and Corporate Financial Planning. Jakarta: PT. Gramedia Main Library.

Ahmad, Firdaus ,. and Abdullah, Wasilah. (2012). Cost Accounting. Jakarta: Salemba Empat.

Ariyanti, Topowijono, and Sulasmiyati. (2016). The effect of profitability and leverage on stock prices (Study of construction and building companies listed on the Indonesia Stock Exchange for the period 20112014). Malang: Journal of Business Administration. Vol. 35 No. 2

Darmaji,Tjptono dan Fakhruddin. (2012). Pasar Modal Di Indonesia (Edisi 3). Jakarta: Salemba Empat

Endri, E (2012). Analisis Teknikal dan Fundamental Saham:Aplikasi Model Data Panel. Jurnal Akuntabilitas,8 (1): $90-96$

Fajri. (2012). Pengaruh PBV EPS ROA ROE DER Dan NPM terhadap Harga Saham Pada Perusahaan Makanan Dan Minuman Yang Terdaftar Di BEI.Makassar : Fakultas Ekonomi. Universitas Muhammadiyah Ponorogo

F.F.G.Ginsu., I.S.Saerang.,F.Roring (2017). Pengaruh Earning Per Share (EPS) Dan Return On Equity (ROE) Terhadap Harga Saham (Studi Kasus pada Industri food \& beverage yang terdaftar di Bursa Efek Indonesia periode 2013-2015). Jurnal EMBA 5, (2), Juni 2017 Page 1327-1336

Harahap, I.M. (2015). Analisis Pengaruh Informasi Laporan Keuangan Terhadap Perubahan Harga Saham Sebelum dan Selama Krisis Ekonomi Indonesia (Studi Kasus Perusahaan Go Public Di BEJ). Jurnal Ilmiah Manajemen dan Bisnis 1 Nomor 2, Juni 2015.

Harwaningrum, M. (2016). Perbandingan Penilaian Saham Dengan Metode Analisis Fundamental Dan Analisis Tehknical, Penggorengan Saham, Serta Keputusan Penilaian Saham Jika Hasil Berlawanan Arah Untuk Kedua Metode Analisis Pada Saham Bakrie Group Untuk Periode 2005-2009. Jurnal Ilmiah Manajemen dan Bisnis 2 Nomor 1, Maret 2016.

Husnan, Suad. (2013). Portfolio Theory and Securities Analysis. YKPN College of Management: Yogyakarta.

Indiantoro, Nur and Supomo. 2014. Business Research Methodology for Accounting \& Management. Yogyakarta: BPFE.

Itabillah. (2013). Pengaruh PBV EPS ROA ROE DER Dan NPM terhadap Harga Saham Pada Perusahaan Property Real Estate Yang Terdaftar Di BEIi. Makassar : Fakultas Ekonomi. Universitas Negeri Semarang. 
Ludiyah, Indri. Wahono, Budi and Priyono, Agus (2017). Pengaruh Return On Asset (ROA), Return On Equity (ROE), Debt to Equity Ratio (DER) dan Earning Per Share (EPS) Terhadap Harga Saham (Studi Empiris pada Perusahaan LQ 45 Yang Terdaftar Di BEI Periode 2012-2016. $e$-Jurnal Riset Manajemen. Fakultas Ekonomi Unisma.

Mayfi, F. Rudianto D. (2014) Analisis Pengaruh Faktor Internal dan Eksternal Perusahaan Terhadap Return Saham. Jurnal MIX Volume IV, Nomor 3, Oktober 2014

Najmiyah, Edy Sujana, Ni Kadek Sinarwati. (2014) Pengaruh Price to Book Value, Price Earning Ratio dan Debt to Equity Ratio Terhadap Return Saham pada Industri Real Estate dan Property yang Terdaftar di Bursa Efek Indonesia Periode 2009-2013. e-Journal S1 Ak Universitas Ganesha. 2(1). Sugiyono (2013). Quantitative, Qualitative and R\&D Research Methods. Bandung: Alfabeta.

Riyanto, Bambang. (2010). Dasar - Dasar Pembelajaran Perusahahaan.Edisi Keempat, Cetakan Kesepuluh, Penerbit Bpfe:Yogyakarta

Syamsuddin, Lukman. 2011. Manajemen Keuangan Perusahaan (Konsep Aplikasi dalam Perencanaan, Pengawasan, dan Pengambilan Keputusan. Edisi Baru. Jakarta: Rajawali Persumber 1, pp.26-42 